\title{
Neurotological Findings at a Health Unit for Adults with Cervicalgia
}

\author{
Bianca Simone Zeigelboim ${ }^{1}$ Vinicius Ribas Fonseca ${ }^{1,2}$ Juliana Cristina Mesti ${ }^{2}$ Leslie Palma Gorski ${ }^{3}$ \\ João Henrique Faryniuk ${ }^{1}$ Jair Mendes Marques ${ }^{1}$ \\ ${ }^{1}$ Department of Otoneurology, Universidade Tuiuti do Paraná, \\ Curitiba, PR, Brazil \\ 2 Department of Otorhinolaryngology, Hospital da Cruz Vermelha,

\begin{abstract}
Address for correspondence Juliana Cristina Mesti, MD, Department of Otorhinolaryngology, Hospital da Cruz Vermelha, filial do Paraná,
\end{abstract} \\ Curitiba, PR, 87050-100, Brazil (e-mail: jumesti@hotmail.com).
} Curitiba, PR, Brazil

3 Subject of Otorhinolaryngology, Universidade Positivo, Universidade

Tuiuti do Paraná, Curitiba, PR, Brazil

Int Arch Otorhinolaryngol 2016;20:109-113.

\begin{abstract}
Keywords

- neck pain

- postural balance

- vestibular function tests

- dizziness

- tinnitus

Introduction The cervical spine is a flexible link between the sensory platform of the skull and torso. The fundamental principle of its operation is due to the balance between muscle strength and flexibility, and any dysfunction of this balance causes neck pain, known as cervicalgia.

Objective The objective of this study is to analyze the most prevalent neurotological findings in adults with neck pain.

Method A cross-sectional study in which 33 adults from 50 to 83 years of age with neck pain were evaluated and underwent the following procedures: anamnesis, as well as ENT, audiological, and vestibular exams.

Results The most evident neurotological symptoms were dizziness (75.7\%), tinnitus, neck cracking, tingling in the extremities, and auditory problems ( $36.3 \%$ for each). The most frequently reported clinical symptoms were related to cardiovascular (69.7\%), endocrine-metabolic (48.5\%), and rheumatic (30.3\%) systems. In the audiological assessment, 30 subjects $(91.0 \%)$ presented hearing impairment in at least one ear, with sensorineural impairment being the most prevalent (88.0\%). In the vestibular assessment, there were alterations in 13 subjects (39.0\%) found in the caloric test. There was a prevalence of alterations in the peripheral vestibular system with a predominance of irritative peripheral vestibular dysfunction.

Conclusion Neurotological complaints were frequent in this population, verifying the importance of these tests in the dysfunctions of the cervical region or the craniocervical junction.
\end{abstract}

\section{Introduction}

It is believed that the cervical spine is one of the most complete joint systems in the human body, allowing the neck to move over 600 times per hour or once every six seconds. ${ }^{1}$

The cervical spine is a flexible link between the sensory platform of the skull and the torso. The fundamental principle of its operation is due to the balance between muscle strength and flexibility, and any impairment of this balance causes neck pain known as cervicalgia. ${ }^{2}$

Cervicalgia has an impact on arthritic and degenerative processes of the cervical segment. It has a higher prevalence in women (68-70\%) and mostly affects people between 42 and 58 years of age. ${ }^{3}$ received

October 29, 2015

accepted

November 6, 2015

published online

March 1, 2016
DOI http://dx.doi.org/

10.1055/s-0036-1572563. ISSN 1809-9777.
Copyright $\odot 2016$ by Thieme Publicações License terms Ltda, Rio de Janeiro, Brazil 
International data show that $1.4 \%$ of visits to doctors in the United States are related to neck pain. In Brazil, it is suggested that up to $55 \%$ of the population will have cervicalgia at some point in their life. ${ }^{3,4}$

Postural balance is maintained from visual, vestibular, and proprioceptive sensory information. Thus, musculoskeletal disorders in the neck can cause changes in the functioning of proprioceptors and a consequent postural disturbance in control called cervical vertigo. ${ }^{5}$

For the authors, ${ }^{6,7}$ aside from the cause shown above that explains cervical vertigo through the change in proprioceptive signs, there are two other possible causes of cervical vertigo. The first is vertebrobasilar insufficiency, which occurs via compression of the vertebral arteries due to osteoarthritic osteophytes or atlantoaxial instability. The second cause can be posterior cervical sympathetic (Barre-Lieou) syndrome, which is caused by an irritation of the labyrinthine artery, which consequently causes a hypoperfusion of the peripheral vestibular system leading to vertigo.

Manifestations of dizziness associated with cervical changes were first described in 1955 by Ryan and Cope, who used the term "cervical vertigo" to refer to a combination of cervical column problems and dizziness. ${ }^{8}$ Cervical vertigo or dizziness has been a controversial topic since then, however, there is much evidence of its existence. Studies in patients with chronic pain and cervicobrachialgia showed cervical vertigo in $50 \%$ of participants. ${ }^{8}$

Postural balance is maintained both by the viscoelastic properties of muscles and by postural adjustments triggered from sensory information. Thus, musculoskeletal disorders in the neck can cause changes in the functioning of proprioceptors causing a disturbance in posture control. $^{5,9}$

Therefore, the aim of this study was to analyze the most prevalent otoneurological findings in adults with cervicalgia.

\section{Method}

This is a cross-sectional study of 33 individuals diagnosed with neck pain: six men (18\%) and 27 women (82\%), aged 50-83 years (mean 67 years old, standard deviation of 5.95 years) referred by a Health Unit.

In terms of lifestyle, five individuals (15.0\%) maintained bad habits, with one being an alcoholic, two being smokers, and two having excessive coffee intake that exceeded $600 \mathrm{mg}$ of caffeine per day, corresponding to $\sim 700 \mathrm{~mL}$ of coffee.

The study included individuals diagnosed with cervicalgia independent of gender. Excluded from the study were subjects who had some type of disorder that prevented important examinations, such as psychological and musculoskeletal impairments and individuals with otological abnormalities such as the presence of earwax, otorrhea, and tympanic membrane perforation.

The study received approval from the Institutional Ethics Committee, protocol number 00047/2008 and individuals underwent evaluation after signing a consent form.

The following procedures were performed:
- Anamnesis - subject received a questionnaire focusing on otoneurological signs and symptoms (Attachment 1).

- ENT evaluation - Conducted to rule out any alterations that could affect the testing.

- Audiological assessment - Conventional tonal audiometry was performed with a Madsen-GN Otometrics brand, Itera model audiometer (São Paulo, Brazil), with TDH-39 headphones, and thresholds in $\mathrm{dB}$ HL. The equipment was calibrated according to ISO 8253 standards. Next, the speech recognition threshold (SRT) was measured as well as the speech recognition index (SRI). Criteria were applied to characterize the degree and type of hearing loss. ${ }^{10,11}$ Vestibular evaluation - Initially, we checked vertigo and verified spontaneous and semi-spontaneous positional nystagmus. Then, for vector-electronystagmography (VENG), we used a three-channel thermosensitive Berger VN316 model device (São Paulo, Brazil) along with a Ferrante swivel chair, a Neurograff model EV VEC visual stimulator, and a Neurograff ear calorimeter model NGR 05 measuring air temperature. Next were eye and labyrinth VNG tests, according to criteria proposed by the authors. ${ }^{12}$

- Eye movement calibration - Verified spontaneous and semi-spontaneous nystagmus using pendular tracking, checking for pre- and post-rotatory plus pre- and postcaloric optokinetic nystagmus. The caloric stimulation time in each ear with air at $42^{\circ} \mathrm{C}$ and $18^{\circ} \mathrm{C}$ lasted 80 seconds for each temperature and responses were recorded with eyes closed and then with eyes open to observe the inhibitory effect of eye fixation (IEEF). The criteria used in the air caloric test were: Absolute value: between 2 and 24 degrees/ sec ( $<2$ degrees/sec (hyporeflexia), $>24$ degrees/ sec (hyperreflexia); Relative values: Labyrinth preponderance $(\mathrm{LP})<41 \%$ and Nystagmus directional preponderance (NDP) $<36 \%{ }^{13}$

\section{Statistical Analysis}

For statistical analysis, we used descriptive statistics methods (frequency distributions) along with Fisher and difference of proportions tests with a significance level of 0.05 (5\%).

\section{Results}

Otoneurological symptoms most evident in the interview were: dizziness (75.7\%), tinnitus, neck cracking, tingling in the extremities and hearing problems (36.3\% for each). The various clinical symptoms that were most evident were: cardiovascular disorders (69.7\%), endocrine-metabolic (48.5\%), and rheumatic (30.3\%), as shown in - Tables 1 and 2 respectively.

The correlation of harmful lifestyle habits (alcohol, cigarettes, and coffee) with complaints of dizziness $(p=0.6503)$, tinnitus $(p=0.2418)$, and the results of audiologic ( $p=0.6004)$ and vestibular $(p=0.4910)$ evaluations showed no significance upon application of Fisher's test.

The interrelationship between the complaints of dizziness, tinnitus, and hearing are noted in - Table 3. 
Table 1 Distribution of frequency for otoneurological complaints in subjects with cervicalgia

\begin{tabular}{|l|l|l|}
\hline Otoneurological symptoms & $\begin{array}{l}\text { Absolute } \\
\text { frequency }\end{array}$ & $\begin{array}{l}\text { Relative } \\
\text { frequency }\end{array}$ \\
\hline Dizziness & 25 & 75.7 \\
\hline Tinnitus & 12 & 36.3 \\
\hline Neck cracking & 12 & 36.3 \\
\hline Tingling of extremities & 12 & 36.3 \\
\hline Hearing loss & 12 & 36.3 \\
\hline Headache & 10 & 30.3 \\
\hline $\begin{array}{l}\text { Difficulty or pain } \\
\text { when moving the neck }\end{array}$ & 10 & 30.3 \\
\hline $\begin{array}{l}\text { Radiating pain to } \\
\text { shoulders and / or arms }\end{array}$ & 9 & 27.2 \\
\hline Fatigue & 5 & 15.1 \\
\hline Agitation during sleep & 5 & 15.1 \\
\hline Dysphagia & 4 & 12.1 \\
\hline Blurred vision & 3 & 9.0 \\
\hline Dysphonia & 2 & 6.0 \\
\hline Double vision & 1 & 3.0 \\
\hline Tremors & 1 & 3.0 \\
\hline Tingling of the face & 1 & 3.0 \\
\hline Dysarthria & 1 & 3.0 \\
\hline Change in sense of taste & 1 & 3.0 \\
\hline
\end{tabular}

Table 2 Other clinical findings related to diverse systems in subjects with cervicalgia

\begin{tabular}{|l|l|l|}
\hline Diverse clinical symptoms & $\begin{array}{l}\text { Absolute } \\
\text { frequency }\end{array}$ & $\begin{array}{l}\text { Relative } \\
\text { frequency }\end{array}$ \\
\hline $\begin{array}{l}\text { Cardiovascular disorders } \\
\text { (high or low pressure) }\end{array}$ & 23 & 69.7 \\
\hline $\begin{array}{l}\text { Endocrine and metabolic } \\
\text { disorders (dyslipidemia, } \\
\text { diabetes, thyroid gland) }\end{array}$ & 16 & 48.5 \\
\hline $\begin{array}{l}\text { Rheumatic disorders } \\
\text { (arthritis, osteoporosis) }\end{array}$ & 10 & 30.3 \\
\hline Head trauma & 4 & 12.1 \\
\hline Kidney disease & 1 & 3.0 \\
\hline Respiratory failure & 1 & 3.0 \\
\hline
\end{tabular}

The application of the difference of proportions test showed significance for dizziness in individuals with hearing complaints ( $p=0.0245)$ and tinnitus ( $p=0.0133$ ).

In the audiological evaluation, 30 individuals (91.0\%) had some kind of hearing impairment in at least one ear, with sensorineural loss being the most prevalent (88.0\%) and three patients $(9.0 \%)$ had hearing thresholds within the normal range, as denoted in - Table 4 . The results of the SRT and the SRI were compatible with the tonal threshold.
For the application of the difference of proportions test among individuals with sensorineural hearing loss and those with hearing thresholds within the normal range, the difference was significant to both ears $(p=0.0000)$.

The relationship between dizziness and the vestibular examination showed eight cases of dizziness in patients with abnormal vestibular test results and 17 cases of dizziness with normal vestibular examination results. Fisher's test did not show statistical significance $(p=0.1317)$, although a large number of individuals had complained of symptoms, even those with normal test results.

The research of positional nystagmus, eye movement calibration, research of semi-spontaneous and spontaneous nystagmus with open and closed eyes, optokinetic and pendular tracking, as well as for and pre- and post-rotatory nystagmus showed no alterations.

Table 3 Correlation among complaints of dizziness, tinnitus, and hearing loss in subjects with cervicalgia

\begin{tabular}{|c|c|c|c|}
\hline \multicolumn{4}{|c|}{ Subjects with dizziness } \\
\hline \multirow[t]{2}{*}{ Complaint } & \multicolumn{2}{|c|}{ Present } & \multirow[t]{2}{*}{$P$} \\
\hline & Yes & No & \\
\hline Hearing loss & 12 & 13 & 0.8025 \\
\hline Tinnitus & 15 & 10 & 0.2077 \\
\hline \multicolumn{4}{|c|}{ Subjects with hearing loss } \\
\hline \multirow[t]{2}{*}{ Complaint } & \multicolumn{2}{|c|}{ Present } & \multirow[t]{2}{*}{$\mathrm{P}$} \\
\hline & Yes & No & \\
\hline Dizziness & 12 & 4 & 0.0245 \\
\hline Tinnitus & 8 & 8 & 1.0000 \\
\hline \multicolumn{4}{|c|}{ Subjects with tinnitus } \\
\hline \multirow[t]{2}{*}{ Complaint } & \multicolumn{2}{|c|}{ Present } & \multirow[t]{2}{*}{$\mathrm{P}$} \\
\hline & Yes & No & \\
\hline Dizziness & 10 & 2 & 0.0133 \\
\hline Hearing loss & 8 & 4 & 0.2068 \\
\hline
\end{tabular}

The application of a difference of proportions test showed significance in the correlation among dizziness complaints with hearing loss $(p=0.0245)$ and tinnitus $(p=0.0133)$.

Table 4 Findings from audiological evaluation in subjects with cervicalgia

\begin{tabular}{|l|l|l|}
\hline Audiological exam result & $\begin{array}{l}\text { Absolute } \\
\text { frequency }\end{array}$ & $\begin{array}{l}\text { Relative } \\
\text { frequency }\end{array}$ \\
\hline Sensorineural hearing loss in RE & 29 & 43.94 \\
\hline Sensorineural hearing loss in LE & 27 & 40.91 \\
\hline Hearing thresholds normal in LE & 5 & 7.58 \\
\hline Hearing thresholds normal in RE & 4 & 6.06 \\
\hline Mixed hearing loss in LE & 1 & 1.52 \\
\hline
\end{tabular}

Abbreviations: LE, left ear; RE, right ear.

The application of a difference of proportions test among subjects with sensorineural hearing loss and subjects with hearing thresholds with normal parameters showed significance in both ears $(p=0.0000)$. 
In the caloric test, 20 subjects (61.0\%) had normal reflexes, six individuals (18.0\%) presented unilateral labyrinthine hyperreflexia, four individuals (12.0\%) had bilateral labyrinthine hyperreflexia, two individuals (6.0\%) presented bilateral labyrinthine hyporeflexia, and one individual (3.0\%) had asymmetrical labyrinthine preponderance (LP).

There were 13 patients (39.0\%), with peripheral vestibular dysfunction, 10 cases (30.3\%) of peripheral vestibular irritant dysfunction, and three cases (9.1\%) of peripheral vestibular deficit dysfunction. The vestibular exam was normal in 20 patients $(61.0 \%)$, as described in - Table 5 .

The application of the difference of proportions test showed no significant difference between the proportions of individuals with normal test results and altered vestibular exams ( $p=0.0786$ ). Although there was no significance, the results showed a high incidence of altered cases for the labyrinthine examination.

\section{Discussion}

In the medical history analysis, we found multiple otoneurological complaints with a higher prevalence of dizziness, then tinnitus, followed by neck cracking, tingling in the extremities, and hearing loss. These symptoms have also been highlighted in several studies ${ }^{9,14,15}$ describing dizziness, tinnitus, and hearing loss as being the most frequent otoneurological complaints in cervical alterations.

In one study, ${ }^{16}$ the authors evaluated 76 patients $20-83$ years old with cervical alterations and the main complaints reported in the medical history were dizziness (96.0\%), tinnitus (81.6\%), and hearing loss (64.5\%). To maintain balance, the cervical somatosensory (proprioceptive), vestibular, and visual systems receive information regarding posture, position, and movements of the head and eyes. For proper integration of these systems, the proper functioning of the head-neck-eye complex is essential as these structures are related to information from the receptors located on the capsule of the zygapophyseal joints and intrinsic muscles of the neck. The stimuli pass through spinal vestibular pathways to lower vestibular nuclei and the central region of the

Table 5 Result of vestibular exam in subjects with cervicalgia

\begin{tabular}{|l|c|c|}
\hline Result of vestibular exam & $\begin{array}{l}\text { Absolute } \\
\text { frequency }\end{array}$ & $\begin{array}{l}\text { Relative } \\
\text { frequency }\end{array}$ \\
\hline Normoreflexia & 20 & 61.0 \\
\hline UIPVD & 6 & 18.0 \\
\hline BIPVD & 4 & 12.0 \\
\hline BDPVD & 2 & 6.0 \\
\hline UDPVD & 1 & 3.0 \\
\hline
\end{tabular}

Abbreviations: BDPVD, bilateral deficit peripheral vestibular dysfunction; BIPVD, Bilateral irritative peripheral vestibular dysfunction; UDPVD, unilateral deficit peripheral vestibular dysfunction; UIPVD, Unilateral irritative peripheral vestibular dysfunction.

The application of a difference of proportions test showed no significance among the proportions of subjects with normal and altered vestibular exams $(p=0.0786)$. Despite not having significance, the result showed a high incidence of altered cases in the labyrinthine exam. cerebellum, along with the ocular afferent tracts. ${ }^{17}$ Cervical proprioception is extremely important in postural control and cervical disorders are often associated with complaints of dizziness and vertigo. ${ }^{17}$

For authors in another study, ${ }^{18}$ the emergence of tinnitus is due to the dynamic interaction of various centers of the nervous and limbic systems and alterations or lesions in the cochlea precede this process. This leads to imbalance in the lower pathways of the auditory system, resulting in abnormal neural activity perceived and interpreted by the central nervous system as tinnitus. The authors also refer to the possibility of afferents from the cervical structures with projections for the cochlear nucleus, indicating an influence of reflection of the cervical spine. Another study ${ }^{19}$ refers to other autonomic disorders as concomitant symptoms of cervicalgia.

With regard to the various clinical findings, we highlight a higher occurrence of systemic diseases such as endocrinemetabolic cardiovascular and rheumatic disorders. In one study, the authors ${ }^{20}$ analyzed 70 medical records to evaluate the most common chronic diseases that affected adults, and found a higher prevalence of cardiovascular diseases, followed by rheumatic, allergic, and endocrine-metabolic diseases. It is noteworthy that the majority of participants in this study consisted of individuals who are prone to the occurrence of these diseases.

In the present study, regardless of not having observed significance in the relationship between excessive consumption of coffee, alcohol, or tobacco with complaints of dizziness, tinnitus, nor in the results of auditory and vestibular tests, it is known that these are potentially harmful habits that are toxic to the inner ear and should be eliminated because they may lead to increased cochleovestibular symptoms. ${ }^{21}$

In the interrelation between otoneurological complaints, there was a higher prevalence of dizziness in individuals with hearing complaints and tinnitus. For the authors, ${ }^{9}$ dizziness, tinnitus and hearing loss can also be clinical manifestations of postural system impairment. The origin of tinnitus is a contentious issue and, among the various existing theories, it is caused by increased spontaneous neuronal activity along the auditory pathways, often associated with lesions of the inner ear and the vestibulocochlear nerve. ${ }^{22-25}$ Furthermore, there may be a dynamic interaction between various regions of the central nervous system, between cochlear nuclei and the pontine region, important for the control of eye movements, along with the areas involved neural interaction of the pons, cerebellum, and vestibular nuclei. ${ }^{22-24}$ For authors in one study, ${ }^{26}$ tinnitus can be the first manifestation of a labyrinthine disease process, before the onset of vestibular dysfunction.

The audiological evaluation showed higher prevalence of sensorineural alteration. One study ${ }^{16}$ evaluated 76 patients with cervical spine alterations and observed a high frequency (61.8\%) of sensorineural hearing loss.

The relationship between dizziness and the vestibular examination predominated normal exams in subjects with dizziness. With the low diagnostic sensitivity of VNG, some individuals with labyrinthine alterations may qualify within normal standards. ${ }^{27}$ 
In the present study, we observed changes in the peripheral vestibular system, located in the caloric test, with a predominance of irritative vestibular dysfunction. These findings were also highlighted by another study ${ }^{28}$ that evaluated 10 patients with cervical vertigo and mentioned peripheral vestibular alteration of the irritant type in $80 \%$ of patients evaluated. Other studies ${ }^{9,29}$ showed that the muscles located in the sub-occipital space provide adequate cervical proprioception for having large numbers of neuromuscular receptors. The cervical tonic muscles work with afferent information from cervical-cochlear and cervical-ocular reflexes, also influenced by information from the vestibular and visual system, allowing adjustments to the position of the head, eyes and to posture. The cervical-cochlear reflex activates the muscles of the neck in response to stretching, to maintain the position of the head; the cervical-ocular reflex works with the vestibular-ocular and optokinetic structures, acting on the extraocular muscles to allow proper vision during movement, and cervical tonic reflex is integrated into the vestibule-spinal to control posture. When a cervical change, and consequently a proprioceptive commitment, occurs, there is an increase in latency of the vestibular-ocular and cervicalocular reflex. This is manifested by the change in finecontrol eye movement that may cause important labyrinthine commitment. A study ${ }^{30}$ applied static and dynamic balance tests on 92 patients with neck pain and observed imbalance and dizziness in $65 \%$ of patients.

\section{Conclusion}

The most common otoneurological symptoms found in our study were dizziness, tinnitus, neck cracking, tingling in the extremities, and hearing loss. The various clinical symptoms most frequently reported were cardiovascular, endocrinemetabolic, and rheumatic.

There was significance for dizziness in individuals with hearing complaints and with tinnitus.

In the audiological evaluation, there was a prevalence of sensorineural alteration (88.0\%) in at least one ear.

The alteration in the vestibular examination occurred in $39.4 \%$ of subjects, evidenced in the caloric test, with a predominance of an irritative dysfunction of the peripheral vestibular system.

\section{References}

1 Natour J. [org.]. Coluna vertebral: conhecimentos básicos. 2nd ed. São Paulo: Etcetera; 2004

2 Mercúrio R. Dor. São Paulo: Manole; 1997

3 Teixeira JM, Barros Filho T, Lin TY, Hamani C, Teixeira WGJ. Cervicalgias. Rev Med 2001;80:307-316

4 Goldenberg J. Coluna ponto e vírgula: colocando um ponto final nas dúvidas, colocando vírgulas nos mitos. São Paulo: Atheneu; 2003

5 Souza GS, Gonçalves DF, Pastre CM. Propriocepção cervical e equilíbrio: uma revisão. Fisioter Mov 2006;19(4):33-40

6 Herdman SJ. Reabilitação Vestibular. São Paulo: Manole; 2002
7 Silva A, Silva M, Pereira J. Vertigem cervicogênica: considerações sobre o diagnóstico funcional e a fisioterapia labiríntica. Fisioter Bras 2002;3(4):258-263

8 Reid SA, Rivett DA. Manual therapy treatment of cervicogenic dizziness: a systematic review. Man Ther 2005;10(1):4-13

9 Reis FJJ, Mafra B, Mazza D, Marcato G, Ribeiro M, Absalâo T. Avaliação dos distúrbios do controle sensório-motor em pessoas com dor cervical: uma revisão. Fisioter Mov 2010;23(4):617-626

10 Davis H, Silverman RS. Hearing and deafness. 3 ed. New York: Ed. Holt, Rinehart \& Wilson; 1970

11 Silman S, Silverman CA. Basic audiology testing. In: Silman S, Silverman CA. Auditory diagnosis, principles and applications. San Diego: Singular Publishing Group; 1997. p. 38-58.

12 Mangabeira-Albernaz PL, Ganança MM, Pontes PAL. Modelo operacional do aparelho vestibular. In: (Org) Mangabeira-albernaz PL, Ganança, MM. Vertigem. 2 ed. São Paulo: Moderna; 1976

13 Costa KCF, Silva SMR, Ganança CF. Estudo das provas oculomotoras e vestibulares por meio da vectonistagmografia. Distúrbios Comum 2005;17:315-322

14 Ekvall Hansson E, Månsson NO, Ringsberg KA, Håkansson A. Dizziness among patients with whiplash-associated disorder: a randomized controlled trial. J Rehabil Med 2006;38(6):387-390

15 Lin YC, Lai CH, Chang WH, Tu LW, Lin JC, Chou SW. Immediate effects of ischemic compression on neck function in patients with cervicogenic cephalic syndrome. J Manipulative Physiol Ther 2012;35(4):301-307

16 Araujo CAF, Silva ARA, Moura AAS. Como melhorar a qualidade de vida dos pacientes vestibulopatas com alterações da coluna cervical através da reabilitação vestibular. Rev SORL-RJ 2009; $1(1): 1-12$

17 Kristjansson E, Treleaven J. Sensorimotor function and dizziness in neck pain: implications for assessment and management. J Orthop Sports Phys Ther 2009;39(5):364-377

18 Moreira MD, Marchiori LLM, Costa VSP, Damasceno EC, Gibrin PCD. Zumbido: possível associação com as alterações cervicais em idosos. Int Arch Otorhinolaryngol 2011;15(3):333-337

19 Gatterman MI. Foundations of chiropractic: subluxation. 2. ed. Missouri: Mosby Year Book; 2005

20 Pinelli LAP, Montandon AAB, Boschi A, Fais LMG. Prevalência de doenças crônicas em pacientes geriátricos. Rev Odonto Ciência 2005;20(47):69-74

21 Felipe L, Simões LC, Gonçalves DU, Mancini PC. Avaliação do efeito da cafeína no teste vestibular. Rev Bras Otorrinolaringol (Engl Ed) 2005;71(6):758-762

22 Fukuda Y.Zumbido e suas corelações otoneurológicas. In: Ganança M. Vertigem tem cura? São Paulo: Lemo; 1998. p.171-6.

23 Jastreboff PJ, Sasaki CT. An animal model of tinnitus: a decade of development. Am J Otol 1994;15(1):19-27

24 Sanchez TG, Zonato AI, Bittar RSM, Bento RF. Controvérsias sobre a fisiologia do zumbido. Arq Int Otorhinolaryngol 1997;1(1):2-8

25 Ganança MM, Caovilla HH, Gazzola JM, Ganança CF, Ganança FF. Betaistina no tratamento do zumbido em pacientes com distúrbios vestibulares. Braz J Otorhinolaryngol 2011;77(4):499-503

26 Órfão CAS, Bonaldi LV, Lemos M, Floriano SL. Achados vestibulares em portadores de zumbido. Arq Int Otorhinolaryngol 2001;5(4):1-4

27 Tiensoli LO, Couto ER, Mitre EI. Fatores associados à vertigem ou tontura em indivíduos com exame vestibular normal. Rev CEFAC 2004;6(1):94-100

28 Greters ME, Bittar RSM, Bottino MA, Greters PM. Avaliação do tratamento fisioterápico na vertigem cervical: estudo preliminar. Arq Int Otorhinolaryngol 2007;11(4):406-410

29 Montfoort I, Kelders WP, van der Geest JN, et al. Interaction between ocular stabilization reflexes in patients with whiplash injury. Invest Ophthalmol Vis Sci 2006;47(7):2881-2884

30 Yahia A, Ghroubi S, Jribi S, et al. Chronic neck pain and vertigo: Is a true balance disorder present? Ann Phys Rehabil Med 2009; 52(7-8):556-567 